\title{
Saggy Pants Ordinance Analysis: Disparate Impact versus Respectability
}

\author{
Jason Armstrong \\ Department of Criminal Justice \\ Albany State University \\ 504 College Dr, Albany, GA 31705 \\ United States \\ Sarah Kuck \\ Department of Social Science \\ Albany State University \\ 504 College Dr, Albany, GA 31705 \\ United States
}

\begin{abstract}
The criminalization of how one wears their clothing has been a contentious topic of debate in many communities in the United States. Several municipalities have made it a crime to have "saggy pants". Saggy or sagging pants are defined as the wearing of pants so far below the waist that it exposes one's undergarments to others. This style of wearing one's clothing began in U.S. prisons and spread across the country. While any person of any gender, race, or ethnic background can wear saggy pants, the style is typically associated with a particular demographic: black males. The city of Albany, Georgia passed a law banning saggy pants in 2010. This article reviews the data of saggy pants citations issued and the surrounding constitutional issues of criminalizing a clothing style. From 2011 to 2019, the Albany Police Department issued 1,298 saggy pants citations. 1,237 or 95.3\% were issued to black males and females. White males and females received the remaining $4.7 \%$ of citations. Albany's racial make-up is $73.5 \%$ black, $22.7 \%$ white, and $2.3 \%$ Latino. The constitutionality of the ordinance is also in question. Some judges have ruled against saggy pants ordinances and at least one state has refused to pass such as a law as it was deemed unconstitutional. The current political and social climate requires further scrutiny and evaluation of existing ordinances that inordinately impact minority populations and can impose unintended consequences.
\end{abstract}

Keywords: Saggy pants, disparate impact, politics of respectability

\section{Introduction}

A contentious ordinance introduced in Southwest Georgia is worthy of review and analysis post passage. Further, the current political and social climate requires further scrutiny and evaluation of existing ordinances that inordinately impact minority populations and can impose unintended consequences. Deconstructing an ordinance that focused on alleviating the wearing of saggy pants, will provide insight into the intention and the subsequent results or data associated with the ordinance. Saggy pants can be worn by any person of any race, ethnicity, gender, or age. For the most part, though, saggy pants are identified with young, black males. Critics of saggy pants laws state that the law encourages stereotyping and racial profiling (Williams, 2010). There are two theories on how the saggy pants form of dressing originated, but both begin in prison. The first theory states that prison inmates are not given belts to hold up their pants, therefore, causing the pants to sag. Prison officials state that belts could be used to commit suicide or homicide within the prison (Williams, 2010). The second theory is that prison inmates wore their pants low, partially exposing their buttocks, to communicate their availability for homosexual activity (Williams, 2010). One or both theories may be correct, but either way, when these prisoners returned to society, they continued wearing their pants low. The saggy pants fashion then filtered into hip-hop culture, which began to influence young people to do the same (Williams, 2010). The analysis will include the politics of respectability, which refers to the efforts of black populations to steer away from images or personas that relate to negative stereotypes (Higginbothom 1993). The politics of respectability will provide a useful framework to better understand the intention of the saggy pants ordinance and the data points included will demonstrate the adverse impact. This paper will show the negative impact of the ordinance through the data associated with the issuance of citations that adversely impacts the black population and the general criminal data of the region that demonstrates an increase in criminal activity in the region. Finally, a brief discussion focused on the Constitutionality of the ordinance will provide national context to the ordinance and broader social issue.

The city of Albany is located in Southwest Georgia. Albany has a manager-commission system of local government. The commission is comprised of six people elected from each district within the city. The seventh member is the mayor, who is elected at-large. The mayor is the chairperson of the city commission, and the city manager runs the day-to-day functions of the city. Albany has a population of 72,130 (U.S. Census Bureau, 2020). 
Albany's racial make-up is $73.5 \%$ black, $22.7 \%$ white, and 2.3\% Latino (U.S. Census Bureau, 2020). The Albany Police Department is responsible for enforcing Georgia's laws and the ordinances of the city of Albany. The Albany Police Department has approximately 236 sworn officers.

On November 23, 2010, the Albany City Commission (City of Albany, 2010) amended the public indecency code, with a five to two vote, by adding the following section:

A person commits the offense of public indecency when he or she performs any of the following acts in a place where a person should reasonably expect to be in view of the public: appears wearing pants or skirts more than three inches below the top of the hips (crest of the ilium) exposing the skin or undergarments.

(b)Fines and penalties. A citation shall be issued to the offender and the person shall be subject to a penalty of not less than $\$ 25.00$ on the first offense and not more than $\$ 200.00$ for each subsequent offense. In addition to or in lieu of a fine, the court may order such person to participate in up to 40 hours of court approved community service activities. Violators shall not be subject to arrest or imprisonment for violation of the section, however, the municipal court shall have the same authority as the superior court to enforce obedience to its orders, judgments, and sentences. (Code of Ordinances, 38-147, 2012).

The saggy pants ordinance was crafted and proposed by Commissioner Tommie Postell. According to Postell, the ordinance's goal was to encourage individuals to pull their pants up so as not to expose their undergarments. In multiple media interviews, Postell called the act of wearing one's pants below the waistline, "Disrespectful, obscene, lewd, and leads to the degradation of society" (Sumner, 2010a; Cohilas, 2010a; Sumner, 2010b; Sumner, 2010c; Emert, 2010). Postell believed that no one wants to see another person's underwear while out in public, and the act of wearing saggy pants leads to other criminal activities (Sumner, 2010a; Cohilas, 2010a; Cohilas, 2010b; Sumner, 2010c; Springer, 2010; Sumner, 2010d). Postell did not provide any supporting data or evidence to support this point-of-view. Two commissioners who voted against the ordinance, Christopher Pike and Roger Marietta, argued that the government should not legislate how people dress (Fowler, 2010; Sumner, 2010d). During discussions leading up to the passing of the law, then-Albany Police Chief John Proctor stated that issuing saggy pants citations would be a low priority for his officers. Chief Proctor stated his officers would not seek out saggy pants violators (Sumner, 2010c).

In Georgia, the passing of a saggy pants ordinance happens in one of two ways. One way is to present the law as a referendum to the voters. The second way, as it occurred in Albany, is for the local governing body to craft and vote on the law. Before the passing of Albany's saggy pants ordinance, Commissioner Pike held a town hall forum to allow citizens to voice their opinions. According to Sumner (2010e), of the 20 citizens who attended the meeting, 19 stated they were against the ordinance. The citizens who spoke at the town hall meeting stated they did not like to see children with saggy pants but did not agree with criminalizing it (Sumner, 2010e). The citizens felt time would be better spent mentoring the youth directly. The data will demonstrate the direct impact of the ordinance on the black population in the region.

\section{Data}

The authors submitted an open records request for all saggy pants citations issued, to include the race and gender of each person cited. From 2011 to 2019, the Albany Police Department issued 1,298 saggy pants citations (Albany Police Department, 2020). 1,237 or 95.3\% were issued to black males and females (Albany Police Department, 2020). White males and females received the remaining 4.7\% of citations (Albany Police Department, 2020). See Table 1 for a breakdown of the citations issued.

Table 1. Saggy pants citations issued by year

\begin{tabular}{|l|l|l|l|l|l|l|l|l|l|l|l|}
\hline & 2011 & 2012 & 2013 & 2014 & 2015 & 2016 & 2017 & 2018 & 2019 & Totals & $\begin{array}{l}\% \text { of citations } \\
\text { issued }\end{array}$ \\
\hline Black male & 208 & 199 & 275 & 137 & 71 & 95 & 52 & 70 & 39 & 1146 & $88.3 \%$ \\
\hline Black female & 18 & 31 & 27 & 8 & 0 & 1 & 2 & 2 & 2 & 91 & $7 \%$ \\
\hline White male & 6 & 15 & 9 & 5 & 1 & 2 & 3 & 3 & 1 & 45 & $3.5 \%$ \\
\hline White female & 4 & 8 & 1 & 3 & 0 & 0 & 0 & 0 & 0 & 16 & $1.2 \%$ \\
\hline Totals & 236 & 253 & 312 & 153 & 72 & 98 & 57 & 75 & 42 & 1298 & \\
\hline
\end{tabular}

\section{Framework and Analysis}

The politics of respectability or respectability politics serves as a useful framework to provide further analysis and discussion of the saggy pants ordinance. The politics of respectability harkens back to a 1993 analysis that evaluated the utilization of social norms to elevate marginalized groups (Higginbothom). Specifically, Higginbothom used the example of the women's movement in African American churches in the Progressive Era, and she examines the importance of manners and respectability as core requirements for the furtherance of efforts (1993). The goal of politics of respectability entails the reform of poor personal behavior as an individual strategy 
of reform and uplifts one's social standing (Higginbothom 1993). Further, politics of respectability can be viewed as an attempt at limiting general access, and only allowing the most normed or mainstreamed that are void of any negative stereotypes into successful roles, as noted by Harris (2003). Davis takes the concept one step further and notes that the politics of respectability is a gatekeeping effort that requires respectful tenets to ensure full "citizenship" into society (2014). In a relevant application, the framework has been used to evaluate an institutional dress code at a Historic Black College that also included the "banning" of saggy pants on campus (Davis 2014).

As the data associated with the ordinance demonstrates, the black population is far more adversely impacted (Albany Police Department, 2020). The concept of respectability politics reigns true as the targeted, black population is more impacted, and thus, the ordinance allows for the gatekeeping function to impact the intended audience. Further, the politics of respectability plays into the construction and imposition of the saggy pants ordinance as an encouragement for black males to resist negative stereotypes and thus, negative behavior as cited by the proposer of the ordinance, Postell (Sumner, 2010a; Cohilas, 2010a; Cohilas, 2010b; Sumner, 2010c; Springer, 2010; Sumner, 2010d). Furthering the concept of respectability politics, of the five votes for Albany's saggy pants ordinance, four were from commissioners who were black and one from a white commissioner. The racial split is reminiscent of the politics of respectability, which is an effort from within the black community to impose normed behavior to promote the perception of the race. Of the two votes against the ordinance, one commissioner was black, and the other commissioner was white. The creator of the proposed ordinance, Commissioner Postell, is black. Commissioner Marietta, who is white and voted against the ordinance, argued that it unduly targeted black males (Fowler, 2010). The politics of respectability intends to promote normed values; However, the intention to reduce criminal behavior through the banning of saggy pants is not consistent with crime rates in the region.

In 2010, the city of Albany had a crime rate that was twice the state and national average (USA.com, 2010). In a 2018 article, USA Today highlighted Albany in its " 25 most dangerous cities where crime is soaring" (Stebbins \& Comen). From 2013 to 2018, violent crime in Albany increased 39.2\% from 527.7 per 100,000 people to 734.8 per 100,000 people. Despite the issuance of almost 1,300 citations for saggy pants, the crime rate in Albany still skyrocketed. If the intention of the saggy pants ordinance was in part, to reduce crime the data associated with the issuance of citations should have had an inverse relationship with crime data. Instead, the criminal activity in the region increased, despite the saggy pants ordinance and enforcement through citations.

Disparate impact occurs when a law has an unintentional impact against a protected class of people. In 2010, the U.S. Congress passed the Fair Sentencing Act that reduced the disparity between sentences for possession of crack cocaine and powder cocaine possession. Those sentenced for crack cocaine violations were given much longer sentences. Numerous studies revealed this had a disparate impact on black individuals. The American Civil Liberties Union (ACLU, 2012) found in 2011 that 12,000 people would have their sentences reduced because of the new law. Eighty-five percent of those receiving a sentence reduction were black. Albany's population is $73.5 \%$ black, yet $95.3 \%$ of the saggy pants citations issued were to black individuals (Albany Police Department, 2020). The saggy pants ordinance in Albany has had a disparate impact on the Black community as demonstrated by the data associated with citations. Albany is not alone, and the disparate impact of the saggy pants ordinance can be found in other cities. In 2019, before repealing the law, in Shreveport, Louisiana, 96\% of saggy pants citations were issued to black males (MacNeil, 2019). For broader social change and to eliminate the disparate impact, it is important to review the constitutionality of the saggy pants ordinance.

\section{Constitutionality}

A question surrounding saggy pants laws is whether the law itself is constitutional. Critics of the law argue that the law violates freedom of speech and expression. Those who wear saggy pants state that the style is an expression of their individuality and rebellion against society. Emerson (as cited in Williams, 2010) wrote, "The right of the individual to freedom of expression has deep roots in our history."

This rebellion is similar to the fashions worn by youth in the 1960s and 1970s. The U.S. Supreme Court has ruled that for symbolic speech to be restricted it must meet the standard set forth in United States v. O'Brien (1968). The Court held that:

A government regulation is sufficiently justified if it is within the constitutional power of the Government; if it furthers an important or substantial governmental interest; if the governmental interest is unrelated to the suppression of free expression; and if the incidental restriction on alleged First Amendment freedoms is no greater than is essential to the furtherance of that interest.

The question that must be answered is, does banning of wearing saggy pants further an important or substantial government interest. In addition, what defines an important or substantial government interest? The interpretation of this varies from community to community. Many cities and towns have passed saggy pants laws, while others 
have considered it, but deemed it unconstitutional. Bob Cooper, the Tennessee Attorney General, researched and concluded for the Tennessee General Assembly, which was considering passing a state law against saggy pants, that the law is unconstitutional because it violates freedom of speech (Haltom, 2009).

Local judges in Riviera Beach, Florida, and the Bronx, New York, have ruled their local ordinances were unconstitutional (Williams, 2010). In Riviera Beach, the county judge, who struck down the local ordinance, ruled that while saggy pants are "tacky" and "distasteful," they are an expression of choice and a person's liberty to wear their clothes how they see fit. A former executive director of the NAACP, Dr. Benjamin Chaves, stated the criminalizing of how a person wears the clothing is more offensive than what the law is trying to remedy (Williams, 2010). An additional charge by critics of the law states that passing a saggy pants law is a slippery slope to tread. Opponents of the law propose the question of whether governments will try to legislate how much cleavage a woman can expose or how short a person's shorts can be (Williams, 2010)?

Proponents of the law believe saggy pants wearers are violating public decency standards. Additionally, advocates of the law argue that the cultural reasons for wearing saggy pants, such as rebellion against conformity and imitating hip-hop culture, do not rise to the level of free speech and, therefore, should not be protected (Sinopole, 2008). The U.S. Supreme Court has ruled that all speech, whether written, spoken, or symbolic, is subject to reasonable time, place, and manner limitations (Clark v. Community for Creative Non-Violence, 1984). Based on this holding, courts have upheld the restriction on saggy pants in the workplace and in public schools. In Zalewska v. County of Sullivan (2003), the Second Circuit Court of Appeals held that employers could restrict what employees wear and how they wear it. In the case of Hazelwood School District v. Kuhlmeier (1988), the U.S. Supreme Court held that school officials have great liberty to restrict freedom of speech for the school's orderly administration. The banning of saggy pants in public schools is constitutional. While saggy pants can be restricted in the workplace and school, the U.S. Supreme Court has not considered the saggy pants issue in other public places, such as streets or parks.

If the Supreme Court grants certiorari a challenge to a saggy pants law and listens to arguments, opponents of the ordinance will likely bring up the case of Spence v. Washington (1974) known as the Spence test. The Spence test holds that for expressive conduct to be protected, it must meet a two-prong standard. First, there must be "intent to convey a particularized message" (Williams, 2010, p. 1181). Second, there must be "a likelihood that, in the surrounding circumstances, the message will be understood by those who view it" (Williams, 2010, p. 1181). Further, the Court stated in Spence (1974), "It is firmly settled that under our Constitution the public expression of ideas may not be prohibited merely because the ideas are themselves offensive to some of their hearers." The saggy pants ordinance in Albany could be struck down based on this Supreme Court opinion. As noted earlier, Commissioner Postell viewed saggy pants as "offensive" and "disrespectful" (Sumner, 2010a; Cohilas, 2010a; Sumner, 2010b; Sumner 2010c; Emert, 2010). If that is the spirit of the law, then it is in direct violation of the Court's ruling.

\section{Conclusion}

Advocates of the saggy pants law believe that by enforcing the law, young people will have more respect for themselves and others, and this notion is consistent with concept of respectability politics. Further, advocates believe the youth would do better in school and have better job opportunities presented to them (Fowler, 2010). However, inclusion is more productive than marginalizing a segment of our population that, at times, is already marginalized.

The wearing of saggy pants in public should not be a crime. The citations issued in Albany demonstrate the disparate impact of the ordinance on the black population (Albany Police Department, 2020). The intention of the saggy pants ordinance as viewed through the politics of respectability framework does not serve to disperse normed values or elevate behavior. Quite the contrary, crime rates in the region have only increased since the passage of the ordinance (USA.com, 2010). At a time when the relationships between police and the black population are fractured, a repeal of the ordinance that disparately targets and adversely impacts the black community should be a priority. The City of Albany should review the citation and crime data points and repeal the existing saggy pants ordinance. The timeliness of repeal could draw support from the targeted communities and bridge a community connection. Further, if local government units do not address the unconstitutional ordinance, the state and federal governments should take action.

\section{References}

ACLU. (2012, June 21). Fair Sentencing Act. Retrieved from https://www.aclu.org/issues/criminal-lawreform/drug-law-reform/fair-sentencing-act

Albany Police Department. (2020). Reported incidents of saggy pants from January 2011 through December 2019. Unpublished raw data. 
Albany Police Department. (2012). Albany Police Department Crime Analysis 2011. Retrieved from http://www.albany.ga.us/filestorage/1798/2879/2939/3094/22318/53658/CrimeReport_12_2011.pdf

Bivens ex rel. Green v. Albuquerque Public Schools. 899 F. Supp. 556 (1995).

City of Albany Board of Commissioners. (2010, November 23). Minutes of the regular meeting of the Board of Commissioners of the city of Albany, Georgia. Retrieved from http://www.albany.ga.us/filestorage/1798/1782/6518/6524/18143/cc_min_112310.pdf

Clark v. Community for Creative Non-Violence. 468 U.S. 288. (1984).

Code of Ordinances City of Albany, GA. (2012). Public indecency prohibited. Retrieved from http://library.municode.com/index.aspx?clientID=14374\&stateID=10\&statename=Georgia

Cohilas, K. (2010a). Albany commissioner wants to outlaw saggy pants. http://www.walb.com/story/13132996/albany-commissioner-wants-to-outlaw-saggy-pants

Cohilas, K. (2010b). No more saggy pants! Retrieved from http://www.walb.com/story/13193238/no-more-saggypants

Emert, J. (2010). Commissioner says Albany means business over saggy pants. Retrieved from http://www.walb.com/story/13735161/commissioner-says-albany-means-business-over-saggy-pants

Fowler, C. (2010). Opinions voiced at saggy pants summit. Retrieved from http://www.walb.com/story/13468057/opinions-voiced-at-saggy-pants-summit

Haltom, B. (2009). The Right to Bear Arms ... Bare Butts and Big Bellies. Tennessee Bar Journal, 45(8), 40-41.

Harris, P. (2003). Gatekeeping and Remaking: The Politics of Respectability in African American Women's History and Black Feminism. Journal of Women's History (15)1, 212-220.

Hazelwood School District v. Kuhlmeier. 484 U.S.260. (1988)

Higginbothom, E. (1993). Righteous Discontent: The Women's Movement in the Black Baptist Church, 1880-1920. Cambridge, MA. Harvard University Press

MacNeil, S. (2019, June 12). After shooting of black man, Louisiana city votes to end sagging pants law. Retrieved from https://www.usatoday.com/story/news/nation/2019/06/12/shreveport-louisiana-saggy-pantslaw/1429817001/

Patton, L. (2014). Preserving respectability or blatant disrespect: A critical discourse analysis of the Morehouse College Appropriate Attire Policy and implications for intersectional approaches to examining campus policies. International Journal of Qualitative Studies in Education. 27 (6): 724- 726.

Sinopole, A. (2008). "No saggy pants": A review of the First Amendment issues presented by the state's regulation of fashion in public streets. Penn State Law Review. Retrieved from http://pennstatelawreview.org/articles/113\%20Penn\%20St.\%20L.\%20Rev.\%20329.pdf

Spence v. Washington. 418 U.S. 405. (1974).

Springer, S. (2010). More people speak out on saggy pants. Retrieved from http://www.walb.com/story/13515027/more-people-speak-out-on-saggy-pants

Stebbins, S., \& Comen, E. (2018, March 12). 25 cities where crime is soaring. Retrieved from https://www.usatoday.com/story/news/2018/03/09/25-cities-where-crime-soaring/409912002/

Sumner, J.D. (2010a). Postell: "Pull'em up". Albany Herald. Retrieved from http://www.albanyherald.com/news/2010/sep/08/postell-pull-em-up

Sumner, J.D. (2010b). City changes retiree benefits, discusses pants. Albany Herald. Retrieved from http://www.albanyherald.com/news/201/nov/02/city-changes-retiree-benefits-discusses-pants

Sumner, J.D. (2010c). "Pants on the ground" ordinance moving forward. Albany Herald. Retrieved from http://www.albanyherald.com/news/2010/oct/19/pants-on-the-ground-ordinance-moving-forward

Sumner, J.D. (2010d). Saggy pants ban OK'd. Albany Herald. Retrieved from http://www.albanyherald.com/news/2010/nov/23/saggy-pants-ban-okd

Sumner, J.D. (2010e). Citizens voice opposition at "saggy pants summit". Albany Herald. Retrieved from http://www.albanyherald.com/news/2010/nov/08/citizens-voice-opposition-at-saggy-pants-summit

United States v. O'Brien. 391 U.S. 367. (1968).

U.S. Census Bureau. (2020). State and county quick facts. Retrieved from https://www.census.gov/quickfacts/albanycitygeorgia

USA.com. (2010). Albany, GA crime and crime rate. Retrieved from http://www.usa.com/albany-ga-crime-andcrime-rate.htm

Williams, O. K. (2010). The suppression of a saggin' expression: Exploring the "saggy pants" style within a First Amendment context. Indiana Law Journal, 85(3), 1169-1196.

Zalewska v. County of Sullivan. 316 F.3d 314. (2003). 